\title{
Typology of Tropical Forest Transition Model in Several Watershed, Sumatera Island
}

\section{Widyananto Basuki Aryono $^{1 *}$, Endang Suhendang ${ }^{2}$, I Nengah Surati Jaya ${ }^{2}$, Herry Purnomo $^{2}$}

\author{
${ }^{1}$ Graduate School of Bogor Agricultural University, Dramaga Main Road, Campus IPB Dramaga, Bogor, Indonesia 16680 \\ ${ }^{2}$ Department of Forest Management, Faculty of Forestry, Bogor Agricultural University, Academic Ring Road, Campus IPB \\ Dramaga, PO Box 168, Bogor, Indonesia, 16680
}

\author{
Received, July 25 2018/Accepted, November 12018
}

\begin{abstract}
At a landscape level, forest transitions have complex spatial heterogeneity characteristics, thus the causes, driving force, typology and specific profile characteristics need to be considered for managing and mitigating forest transition. This paper describes how the diversity of forest transition characteristics was grouped and how the characteristic of group was identified. Typology classes within water catchment areas in Riau, North Sumatera and West Sumatera Provinces, Indonesia were investigated by considering social, economic and biophysical aspects. The main study objective was to develop a forest transition typology at a landscape level. The model typology was derived from a clustering method with the Standardized Euclidean Distance. The study found that the most significant factor which successfully differentiated the typology of forest transition into two typologies was the population growth having approximately 92\% of overall accuracy. The first typology (typology 1) could be categorized as rapid forest transition, while the typology 2 was categorized as slow forest transition. The study suggested that the management and mitigation of the impacts of the forest transition should be conducted by considering the landscape typology as a function of the profiles for each typology.
\end{abstract}

Keywords: demography transition, forest transition, landscape, typology

*Correspondence author, email:wb.aryono@gmail.com

\section{Introduction}

Forest transition is a phenomenon of land-use change from forest decreasing phase to forest increasing phase (Mather 1992; Grainger 1995; Mather \& Needle 1998). Decreasing of forest area is due to the use for other purposes such as agricultural cultivation, and settlement, whereas the increasing of forest area is due to the success of forest plantation (Grainger 1995). Several factors influenced to land use change such as demographic, economic, technological, policy, institutional, cultural, biophysical, and infrastructure (Geist \& Lambin 2002). According to data of FAO (2015), the forest area shows a decreasing trend at slowing rate. As a result, the forest decline and population increase will affect human life (Suhendang 2013). The forest transition process has resilience from the influence of various factors and poses potential environmental problems, such as flood disasters in France (Mather et al. 1999), Switzerland (Mather and Fairbairn 2000), Vietnam, and China (Mather 2007). Most countries that experienced an increasing forest area have a history of had the most critical forest area under 20\% (Rudel et al. 2005). Forest transition process forms a new equilibrium of land use between the forest, agriculture, and settlements (Grainger 1995).
Forest transition has previously occurred in European and American countries (Mather 1992), then followed by Asian and African countries (Mather 2007). Forest transition development varied within and among countries due partially to differences in spatial location characteristics, including in Indonesia. In Jambi Provinces, the deforestation rate decreased from 77 thousand per year in 2009 to 25 thousands ha per year in 2015, respectively. Lampung Province experienced a relatively constant deforestation rate between 2009 and 2015, i.e., about 1 thousand ha per year. On the contrary in West Kalimantan Provinces, the deforestation rate increasased from 94 thousand ha per year in 2009 to 125 thousand ha per year in 2015 , respectively. Thus, the variation in the development of forest transition was triggered by the difference in spatial location that caused heterogeneity influencing factors.

Development of a typology model is needed to characterize the spatial heterogeneity of forest transition at the landscape level. Demographic factor, like the population growth rate, is one of the strongest driving factors (Mather and Needle 2000; Barbier \& Burgess 2001). Increasing forest area is influenced by the slowdown population rate and changes in forest-related attitudes and perceptions by 
communities and governments (Mather 1992). Furthermore, population pressure on land is another important driving factor of forest transition (Kothke et al. 2013). In addition to demographic factor, forest transition is closely linked to economic development (Rudel et al. 2010). The relationship between income inequality and income per capita follows the reverse U-curve, known as Environment Kuznet Curve (EKC) (Kuznets 1955). The curve links the decrease and or increase of forest area with income per capita. Increased income per capita affects the phase of declining forest area at low-income level, then at high-income level showed increasing forest area (Antle and Heidebrink 1995; Barbier and Burgess 2001; Ehrhardt-Martinez et al. 2002; Ewers 2006; Bae et al. 2012; Culas 2012). The pattern of EKC was influenced by strong state democracy and population pressure (Barbier and Burgess 2001; Ehrhardt-Martinez et al. 2002). A biophysical condition is one of the predictors of variations in the development of forest transitions.

The development of existing typologies has differences in the influence of specific factors due to differences in location and spatial space. In the global scope, a variety of forest transition phase was based on biophysical factor and categorized into four phases, i.e., pre-transition, early transition, late transition and post transition (Hosonuma et al. 2012). The forest transition phases were closely related to the industrialization stage, i.e. pre-industrial, industrial and post-industrial phases (Mather et al. 1999a). Indonesia was included in the early transition phase (Hosonuma et al. 2012). However, at the landscape level, Indonesia experiences forest transition phases, mainly due to differences in spatial location characteristics. Sumatra Island was classified into the late transition phase; while Java Island was classified into post-transition phase (Kanninen et al. 2009). Forest transition typology model was also developed based on social aspect (Setiawan et al. 2015), socio-economic aspects (Sulistiyono et al. 2015), social and biophysical aspects (Wijaya et al. 2015), as well as biophysical aspects (Rijal et al. 2016). Based on region grouping in the Sumatra Island, the majority of administrative regions in Riau Province were grouped in a typology with the highest deforestation rate (Sulistiyono et al. 2015) and were included in the late deforestation phase (Rijal et al. 2016).

Referring to the explanation, understanding the diversity of forest transition processes at landscape level requires sequential steps starting from identifying the driving forces, developing typology based on identification results and then analyzing characteristics for each typology. The study objective was to develop a forest transition typology model. The model was useful for planning in managing and mitigating the forest transition effects.

\section{Methods}

This study was carried out in Indragiri, Kampar, Siak and Rokan Watersheds. These watersheds are located in 26 regencies and three provinces, namely Riau Province, North Sumatra and West Sumatra, Indonesia. The study area lies between $1^{\circ} 00^{\prime} \mathrm{S}-2^{\circ} 30^{\prime} \mathrm{N}$ latitude and $99^{\circ} 30^{\prime}-104^{\circ} 00 \mathrm{E}$ longitude. Indragiri, Kampar, Siak, and Rokan Watersheds differ in total area, i.e., 2.26, 2.55, 1.12, 2.00 million hectares, respectively. The study was conducted in February-November 2017.

The study used time series land cover data from Ministry of Environment and Forestry spanning from 1990 to 2015. The 2015 land cover data showed an overall accuracy of 96.3\% for forest and non-forest cover classes (KLHK 2017). The land cover data was converted into land use data referring to the FAO (Food and Agriculture Organization) framework (FAO 2012). The modification process utilized a $30 \mathrm{~m}$ resolution of LANDSAT image. The ground truth/reference data were collected from SPOT 6 image with a spatial resolution of $1.5 \mathrm{~m}$ and a Topographic Map of Indonesia (Rupa Bumi Indonesia) with a scale of 1: 50,000 which was obtained from the Geospatial Information Agency (Badan Informasi Geospasial/BIG) in 2012. Topographic data were generated from Shuttle Radar Topographic Mission-Digital Elevation Model (SRTM-DEM) with $30 \mathrm{~m}$ spatial resolution and used ArcGIS software. LANDSAT and SRTM-DEM data were downloaded freely from United States Geological Survey (USGS) website. The socioeconomic data were obtained from the Central Bureau of Statistic (Badan Pusat Statistik/BPS), i.e., Indonesia Decennial Census data of total population in 2002 and 2012, as well as Gross Regional Domestic Product (GRDP) in 2002 and 2012. Road data was also derived from a topographic map of Indonesia with a scale of 1: 50,0000.

The research procedure comprises of six stages. The first stage was carried out to analyze forest transition phenomena in the study site based on the percentage of forest area. Data series of forest area from 1990, 1996, 2000, 2003, 2006, 2009,2012 , and 2015 were used to calculate the percentage of forest area, i.e., the ratio of forest area total land area using Equation [1].

Percentage of forest area $=\frac{\text { forest area }}{\text { total of land area }} \subset 100 \%$

The second stage was to identify the prediction factor by tracing the forest transition literature concerning influencing factors. Then, an assessment was made to check data

Table 1 The predictor variable for forest transition typology model

\begin{tabular}{ll}
\hline \multicolumn{1}{c}{ Independen variables } & \multicolumn{1}{c}{ Unit } \\
\hline Population density $\left(\mathrm{X}_{1}\right)$ & People $\mathrm{km}^{-1}$ \\
Population growth rate $\left(\mathrm{X}_{2}\right)$ & People year \\
Forest per capita $\left(\mathrm{X}_{3}\right)$ & ha people \\
GDRP per capita $\left(\mathrm{X}_{4}\right)$ & IDR Million people \\
GDRP per capita growth rate $\left(\mathrm{X}_{5}\right)$ & IDR Million people year $^{-1}$ \\
Elevation $\left(\mathrm{X}_{6}\right)$ & $\mathrm{mdpl}$ \\
Road density $\left(\mathrm{X}_{7}\right)$ & $\mathrm{km} \mathrm{km}$ \\
\hline
\end{tabular}


availability in relation to these factors. The available data on the socio-economic factor was population growth rate, population density, forest area per capita, income per capita, and income per capita rate. In addition, the available biophysical data were elevation, and road density. The predictor variables are shown in Table 1 . The third stage was to determine the smallest unit of analysis. The smallest unit of analysis in this study is sub-catchment. The fourth stage was to develop a model of forest transition typology. The forest transition typology model was developed using a clustering method based on the Standardized Euclidean Distance (SdED) approach. The distance between two classes was calculated using Equation [2] (Jaya 2015);

$$
S s E D_{j k}=\left[\sum_{i=1}^{n} \frac{\left(x_{i j}-x_{i k}\right)^{2}}{s_{i}^{2}}\right]
$$

note: $\mathrm{SdED}_{j k}=$ Standardized Euclidean Distance; $s_{i}^{2}=$ diversity of variables to- $i ; x_{\mathrm{ij}}=$ variables value $i$ from cluster $j$; $x_{i k}=$ variables value $i$ from cluster $k$.

The proximity description was illustrated by dendrogram grouping. Determination of class separation from dendrogram result was analyzed by variance analysis with $95 \%$ test level. The fifth stage was to test the accuracy of typology model with actual data. Accuracy test was conducted by calculating Overall Accuracy (OA), Producer's Accuracy (PA) and User's Accuracy (UA) with the contingency matrix (Jaya 2015) Equation [3], Equation [4], and Equation [5]

$$
\begin{aligned}
& \text { Overall Accuracy }(\mathrm{OA})=\sum \frac{x_{k k}}{N} \times 100 \% \\
& \text { Producer's Accuracy (PA) }=\frac{x_{k k}}{x_{k+}} \times 100 \%
\end{aligned}
$$

User's Accuracy (UA) $=\frac{x_{k k}}{x_{+k}} \times 100 \%$ note:note: $x_{i i}$ : the diagonal value of the contingency matrix of row to- $i$ and column to- $i ; x_{i+}$ : total number of the contingency matrix of row to- $i ; x_{+i}$ : total number of the contingency matrix of column to- $i ; N$ : total number of observations included in the matrix.

The model selection criteria are models that have the best combination of OA, PA, and UA and built from simple variable components. The research combined the various variables to obtain the best-selected model. The sixth stage was to perform a regression analysis of the relationship between variable selection and transformation natural forest area. This analysis was conducted to find out the trend picture.

The definitions related to forest transitions are used to give specific restriction. Forest is determined as land uses with a more than 0.5 ha, dominated by trees with a higher than 5 meters, and canopy covers of more than $10 \%$, including rubberwood, and excluding oil palm plantation (FAO 2012). Forest transition is defined as a trend of forest areas in the landscape from the decline phase to the expanding phase (Mather 1992; Grainger 1995; Mather \& Needle 1998). The assumption with these trends, factors that do not belong to the variables studied run into harmonies, such as security conditions, technological advances, culture, and politics. The natural forest transformation can be termed deforestation or the phase of decreasing forest area in the development of forest transition.

Furthermore, most of the land transformation can potentially occur reforestation or an opportunity to have increasing forest area phase in the forest transition development. The forest transition typology is a classification of forest transitions based on spatial characteristics within the landscape. Spatial characteristics were tested based on literature study and availability data.

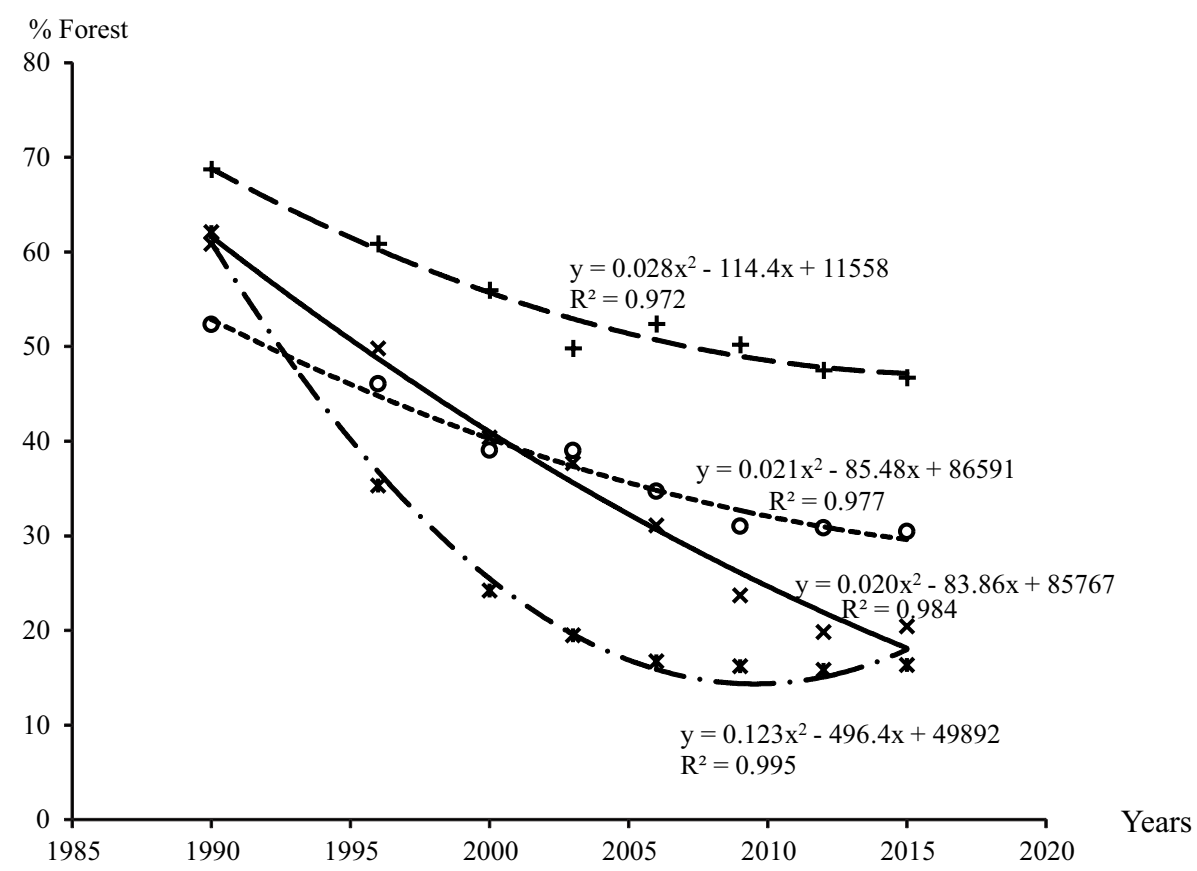

Figure 1 Forest transitions in Kampar, Indragiri, Rokan, and Siak Watersheds. Kampar Watershed ( - - ) Indragiri Watershed $(----)$, Rokan Watershed $(-)$, Siak Watershed $(-\cdot-)$. 


\section{Results and Discussion}

Forest transitions in landscapes The phenomenon of forest transition in Indonesia has not signified forest transition symptoms. Indonesia was covered by 95 millions ha of tropical forest in 2015, which was about $50.6 \%$ of the total land area (MoEF 2017). Tropical forest in Indonesia experienced rapid deforestation rate between 1990 and 2005 and then getting slower between 2005 and 2015. We tracked the tropical forest transition phenomenon in the four selected watersheds. The percentages of forest cover for each selected watershed in the period of 1990-2015 are presented in Table 2 .

Based on Table 2, there is a trend of forest transition in the selected watersheds during the period of 1990-2015. The

Table 2 Percentage of watershed's forest cover in the period of 1990-2015

\begin{tabular}{ccccc}
\hline \multirow{2}{*}{ Year } & \multicolumn{4}{c}{ Percentage of forest cover (\%) } \\
\cline { 2 - 5 } & $\begin{array}{c}\text { Indragiri } \\
\text { watershed }\end{array}$ & $\begin{array}{c}\text { Kampar } \\
\text { watershed }\end{array}$ & $\begin{array}{c}\text { Rokan } \\
\text { watershed }\end{array}$ & $\begin{array}{c}\text { Siak } \\
\text { watershed }\end{array}$ \\
\hline 1990 & 52.3 & 68.7 & 60.8 & 62.1 \\
1996 & 46.0 & 60.7 & 49.8 & 35.2 \\
2000 & 38.9 & 55.2 & 40.3 & 23.2 \\
2003 & 38.8 & 49.5 & 37.6 & 18.3 \\
2006 & 34.5 & 51.4 & 31.0 & 15.3 \\
2009 & 30.6 & 48.6 & 23.5 & 14.0 \\
2012 & 29.8 & 45.0 & 19.0 & 13.7 \\
2015 & 30.0 & 45.2 & 20.0 & 14.5 \\
\hline
\end{tabular}

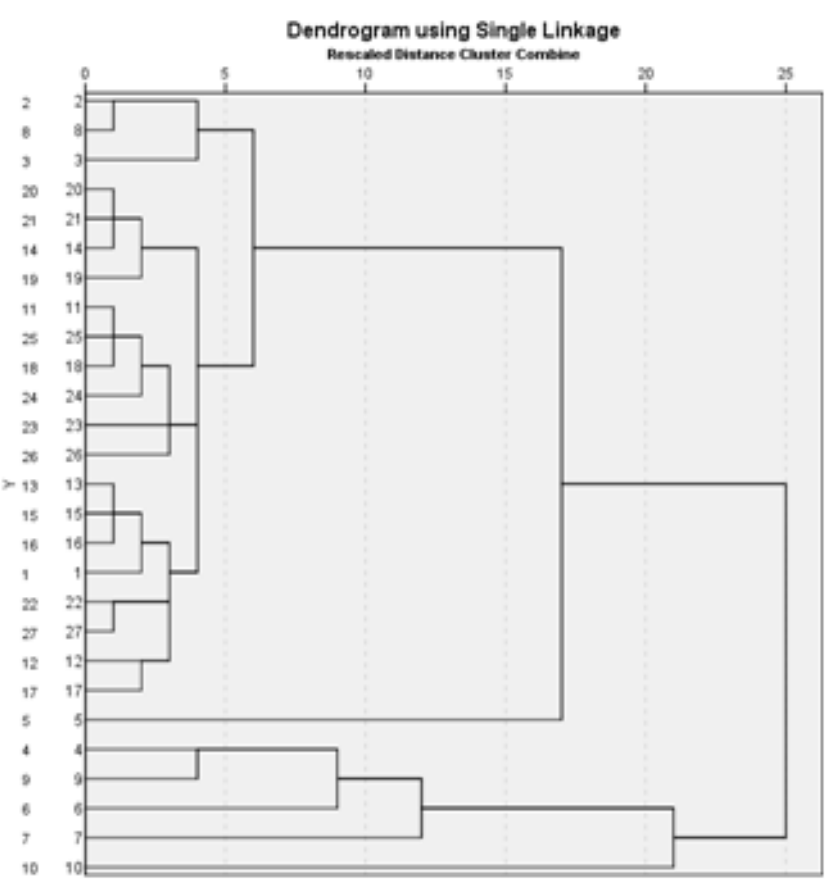

trendline of forest transition for each watershed can be seen in Figure 1. The selected watersheds have a gradually decreased trend, and there is a sign of a turning point of expanding forest area, especially in 2015. Declining forest area was due to the transformation of natural forest into other land uses, i.e., agricultural cultivation purposes, settlements and partly shrubs. Expanding forest area was mainly due to the successful development of forest plantations and rubber estates.

There are two common characteristics regarding the pattern of decreasing forest area, i.e., drastic decrease and gradual decrease. The drastic decrease of forest area was characterized by a very high rate of forest decline. On the contrary, the gradual decrease pattern had a characteristic of

Table 3 Correlation test of selected variables

\begin{tabular}{llllll}
\hline & $\mathrm{Y}$ & $\mathrm{X}_{2}$ & $\mathrm{X}_{3}$ & $\mathrm{X}_{4}$ & $\mathrm{X}_{5}$ \\
\hline $\mathrm{Y}$ & 1 & & & & \\
$\mathrm{X}_{2}$ & 0.631 & 1 & & & \\
$\mathrm{X}_{3}$ & 0.693 & 0.271 & 1 & & \\
$\mathrm{X}_{4}$ & 0.410 & 0.323 & 0.122 & 1 & \\
$\mathrm{X}_{5}$ & 0.241 & 0.481 & 0.131 & -0.070 & 1 \\
\hline
\end{tabular}

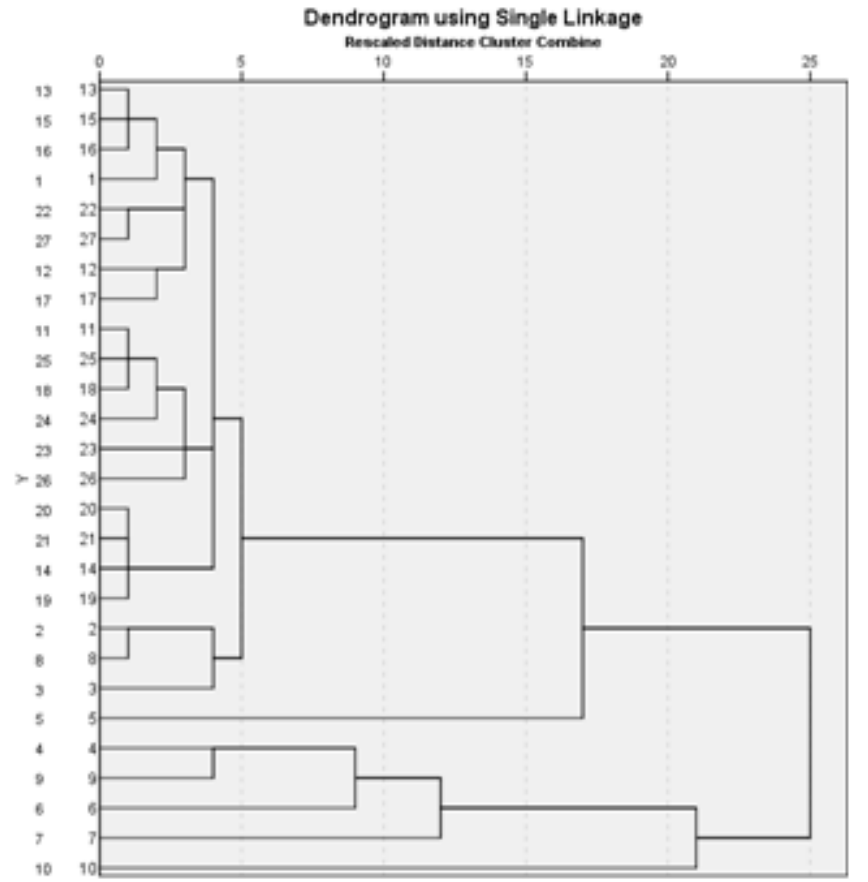

Figure 2 Dendrogram test result left side shows population growth rate variables $\left(\mathrm{X}_{2}\right)$ and right side shows $(\mathrm{b})$ the interaction $\mathrm{X}_{2} \mathrm{X}_{3} \mathrm{X}_{4} \mathrm{X}_{5}$. 
Table 4 Recapitulation of accuracy test results with 2 classes

\begin{tabular}{ccccccccc}
\hline Accuracy test & $\mathrm{X}_{2}$ & $\mathrm{X}_{3}$ & $\mathrm{X}_{4}$ & $\mathrm{X}_{5}$ & $\mathrm{X}_{2} \mathrm{X}_{3}$ & $\mathrm{X}_{2} \mathrm{X}_{4}$ & $\mathrm{X}_{2} \mathrm{X}_{5}$ & $\mathrm{X}_{2} \mathrm{X}_{3} \mathrm{X}_{4} \mathrm{X}_{5}$ \\
\hline OA & $92 \%$ & $78 \%$ & $89 \%$ & $89 \%$ & $92 \%$ & $92 \%$ & $92 \%$ & $92 \%$ \\
\hline SmallestPA & $89 \%$ & $67 \%$ & $89 \%$ & $80 \%$ & $89 \%$ & $89 \%$ & $89 \%$ & $89 \%$ \\
\hline Smallest UA & $89 \%$ & $67 \%$ & $80 \%$ & $89 \%$ & $89 \%$ & $89 \%$ & $89 \%$ & $89 \%$ \\
\hline
\end{tabular}

population density $\left(\mathrm{X}_{1}\right)$, population growth rate $\left(\mathrm{X}_{2}\right)$, forest per capita $\left(\mathrm{X}_{3}\right)$, GRDP per capita $\left(\mathrm{X}_{4}\right)$, GDP per capita growth rate $\left(\mathrm{X}_{5}\right)$, Elevation $\left(\mathrm{X}_{6}\right)$, Road Density $\left(\mathrm{X}_{7}\right)$

Table 5 Recapitulation of accuracy test results with 3 classes

\begin{tabular}{ccccccccc}
\hline Accuracy test & $\mathrm{X}_{2}$ & $\mathrm{X}_{3}$ & $\mathrm{X}_{4}$ & $\mathrm{X}_{5}$ & $\mathrm{X}_{2} \mathrm{X}_{3}$ & $\mathrm{X}_{2} \mathrm{X}_{4}$ & $\mathrm{X}_{2} \mathrm{X}_{5}$ & $\mathrm{X}_{2} \mathrm{X}_{3} \mathrm{X}_{4} \mathrm{X}_{5}$ \\
\hline OA & $85 \%$ & $74 \%$ & $67 \%$ & $70 \%$ & $85 \%$ & $92 \%$ & $85 \%$ & $85 \%$ \\
\hline Smallest PA & $67 \%$ & $33 \%$ & $14 \%$ & $25 \%$ & $67 \%$ & $50 \%$ & $67 \%$ & $67 \%$ \\
\hline Smallest OA & $67 \%$ & $33 \%$ & $33 \%$ & $33 \%$ & $67 \%$ & $50 \%$ & $67 \%$ & $67 \%$ \\
\hline
\end{tabular}

Population Density $\left(\mathrm{X}_{1}\right)$, Population Growth Rate $\left(\mathrm{X}_{2}\right)$, Forest Per Capita $\left(\mathrm{X}_{3}\right)$, GRDP per capita $\left(\mathrm{X}_{4}\right)$, GDP per capita growth rate $\left(\mathrm{X}_{5}\right)$, Elevation $\left(\mathrm{X}_{6}\right)$, Road Density $\left(\mathrm{X}_{7}\right)$

low forest declining rate. The pattern of the drastic decline occurred in the Rokan and Siak Watersheds. Between 1990 and 2015, the forest cover of Rokan and Siak Watersheds declined by $1.6 \%$ and $1.8 \%$ per year, respectively. These values were significantly higher compared to those in Indragiri and Kampar Watersheds that experienced gradual forest decline, i.e., $0.9 \%$ per year.

There is a variation of forest area expansion in the selected watershed. Forest plantations and rubber estates dominated forest area expansion. Kampar Watershed in the period of 1990-2015 had the highest increase of forest area compared to other watersheds, i.e., 19\%. The percentages increase of forest area in Siak, Indragiri, and Rokan Watersheds were $14.5 \%, 7 \%$, and $5 \%$ respectively.

Model of forest transition typology The result of variance analysis indicated that the independent variables which significantly influence land use change were population growth rate $\left(\mathrm{X}_{2}\right)$, forest area per capita $\left(\mathrm{X}_{3}\right)$, GRDP per capita $\left(\mathrm{X}_{4}\right)$, and GRDP per capita rate $\left(\mathrm{X}_{5}\right)$. Furthermore, the correlation of selected variables to the magnitude of forest changes was carried out using the correlation test. The result of the analysis was used for grouping tests. The correlation test results are shown in Table 3 .

Areas which run into the land transformation from natural forests were grouped into homogeneous classes. The results of the grouping of various predictor variables formed a proximity dendrogram. This dendrogram explains the closeness of the class that is formed. Typical test results of various independent variables and their combinations are shown in Table 4. This group was divided into two classes, i.e., area with rapid, and low forest transition. The population growth rate variable $\left(\mathrm{X}_{2}\right)$ showed the highest combination of OA, PA, and UA at the accuracy test, i.e., $92 \%, 89 \%$, and $89 \%$ respectively. The GRDP per capita $\left(\mathrm{X}_{4}\right)$ performed better than, GRDP per capita growth rate $\left(\mathrm{X}_{5}\right)$ and forest area per capita $\left(\mathrm{X}_{3}\right)$ (Table 4$)$. We combine various variables, for example population growth rate $\left(\mathrm{X}_{2}\right)$ and forest area per capita $\left(\mathrm{X}_{3}\right)$, population growth rate $\left(\mathrm{X}_{2}\right)$ and GRDP per capita $\left(\mathrm{X}_{4}\right)$, as well as population growth rate $\left(\mathrm{X}_{2}\right)$ and GRDP per capita growth rate $\left(\mathrm{X}_{5}\right)$, to test whether there is an increasing overall accuracy. The results indicated that there was no significant increase in accuracy compared to the best single variable accuracy. Combination of 4 variables such as population growth rate $\left(\mathrm{X}_{2}\right)$, forest area per capita $\left(\mathrm{X}_{3}\right)$, GRDP per capita $\left(\mathrm{X}_{4}\right)$, and GRDP per capita growth rate $\left(\mathrm{X}_{5}\right)$ did not improve the accuracy as well. The dendrogram results from the comparison of the best single variable and the combination of the various variable are shown in Figure 3. Thus, the population growth rate is the best predictor of forest transition in the study area.

The typology model was also developed using three classes, i.e., rapid, middle and low forest transition (Table 5). Based on the accuracy assessment, typology model which was developed using population growth rate (X2) obtained the highest accuracy. Combining several variables into the model did not increase the accuracy significantly.

The selection of typology models was based on OA, PA, and UA values. Based on these value, the forest transition typology model with two classes was better than three 
classes. Thus, the typology model with two classes using population growth rate as the predictor variable was selected. The selected model yielded OA, PA and UA values of $92 \%$, $89 \%$, and $89 \%$, respectively. The classes of the model were rapid transition region (Typology 1) and slow transition region (Typology 2).

The result of this study suggested that the specific variable for the formation of forest transition typology was the population growth rate. The spatial characteristics of potential forest transition have very high proximity to the spatial characteristics of demographic transition. Typology 1 was characterized by areas with rapid population growth, i.e., The area belonging to typology 1 has a population growth rate of 14.5 thousand people per year. Areas under Typology 1, so-called rapid forest transition region, have a high probability of experiencing a rapid forest transition. The land

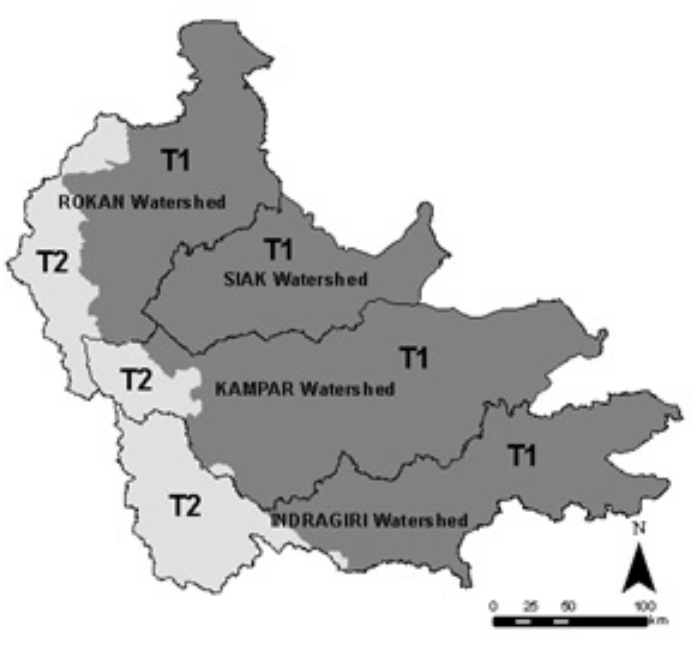

Figure 3 Spatial model of forest transition typology. watershed boundary $(\square)$, typology $1(\square)$, typology 2 (口).

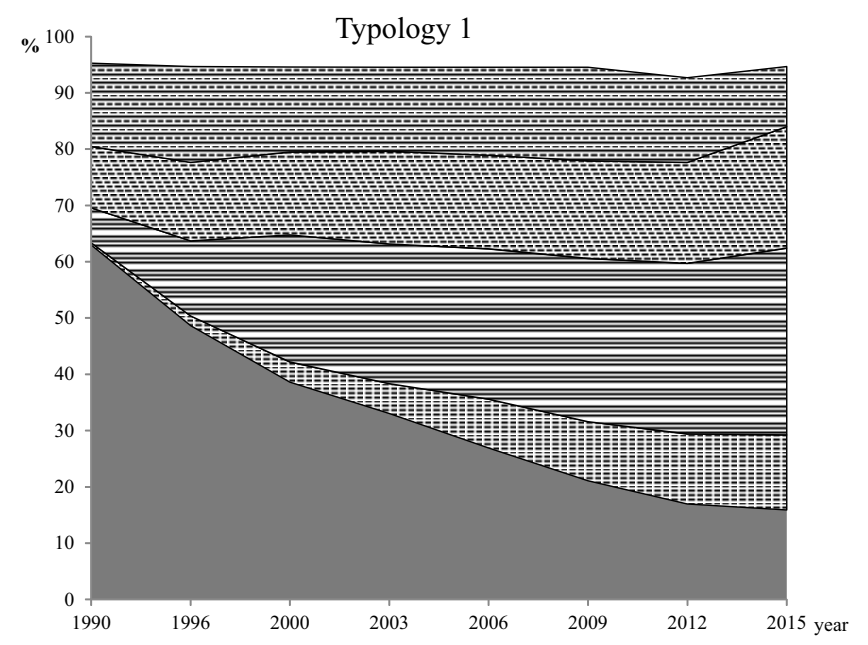

transformation rate from natural forests to other land uses was 9,680 ha per year.

On the contrary, Typology 2, so-called slow forest transition region, was characterized by slow population growth rate, i.e., 3.5 thousand people per year. The rate of land transformation from natural forests to other land uses was 1,005 Ha per year. These results suggested that within the catchment area there is spatial heterogeneity of demographic transition characteristics that shape the characteristics of forest transitions. The spatial distribution of the forest transition typology model can be seen in Figure 3.

The forest transition typology model based on the population growth rate is an appropriate way to explain actual forest transition characteristics. Areas that have rapid population growth tend to convert natural forests into other

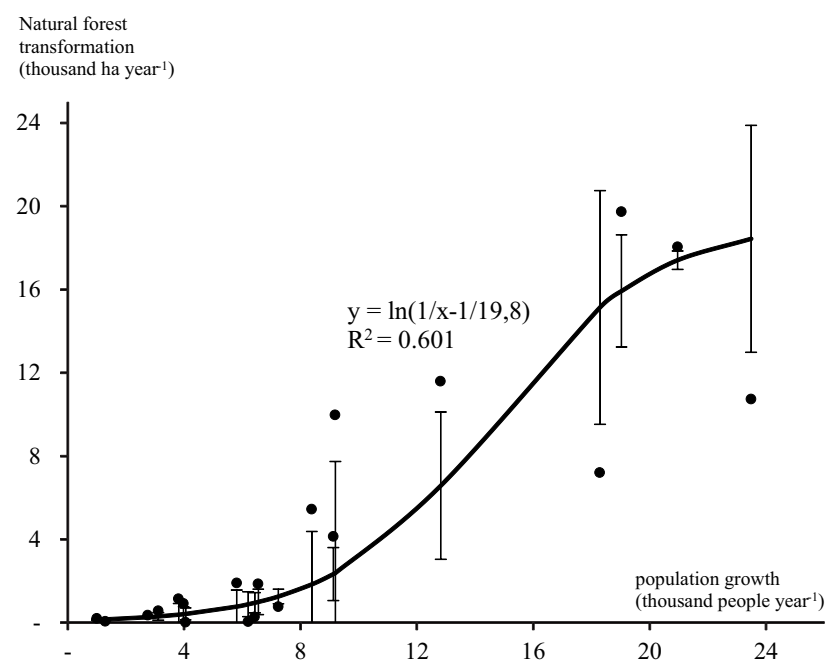

Figure 4 Relationship between land transformation and population growth.

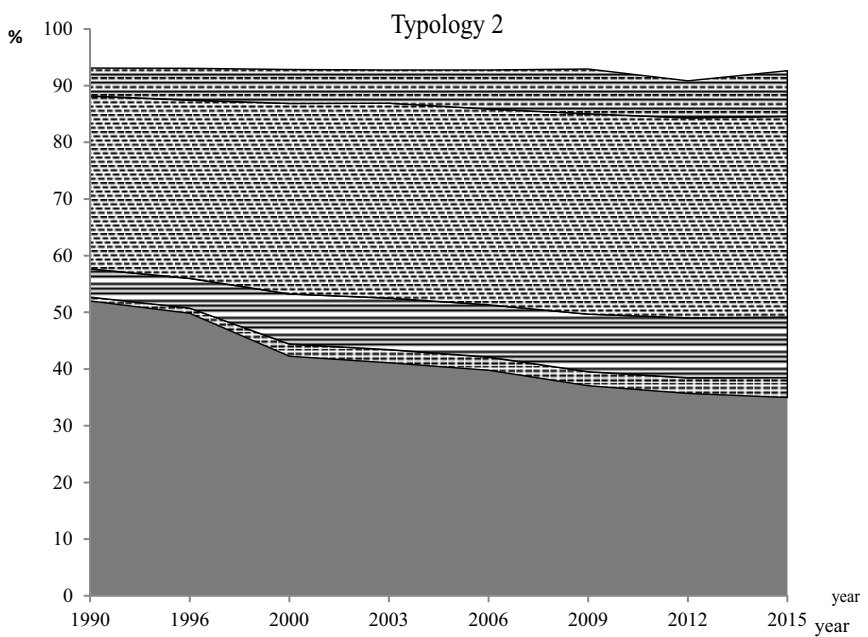

Figure 5 Trajectory land use based on typology. Shrubs ( $\Xi$ ), Agroforestry ( $\Xi$ ), Palm oil plantations ( ), Forest and rubber plantations $(\Xi)$, and Natural forests $(\because)$. 
land uses, especially for cultivation purposes and settlements. However, it is different from areas with slow population growth characteristics that tend to retain natural forests.

From the typology results, we continue to analyze the relationship between demographic transition and forest transition using population growth rate as the main indicator and simple regression analysis. The relationship between natural forest transformation as an indication of forest transition and population growth follows a sigmoid curve, which is presented in Figure 4. Based on the relationship, when the population growth is low, the process of natural forests transformation is getting slow, and vice versa. Thus, demographic and forest transition have similar characteristics.

Landuse trajectory The land use trajectory in the study area according to the forest transition typology model was composed of rapid and slow transition characteristics, (Figure 5). The land use trajectory describes the balancing process of land transformation between forestry and agriculture sectors, i.e., conversion of natural forest to cultivated land. In areas with rapid transition characteristics, land use trajectories tended to be dominated by land transformation processes from natural forests to land use for cultivation purposes. Oppositely, in areas with slow transition characteristics, land cover was dominated by natural forests. Areas with high population growth characteristics tend to encourage adaptation in improving welfare by land transformation from natural forests into land use for cultivation purposes.

In the early 1990s, the land uses of Typology 1 areas composed of natural forest, forest plantation, palm oil, agroforestry, shrubs, and other uses for example settlements, with percentage values of $63.95 \%, 0.39 \%, 6.22 \%, 10.87 \%$, $14.82 \%$, and $3.75 \%$ respectively. From 1990 to 2015 , around $47 \%$ of the natural forest were converted to forest plantation and rubber estates $(11.77 \%)$, palm oil (18.36\%), agroforestry $(7.95 \%)$, shrubs $(8.70 \%)$, and other land-use such as transmigration, settlements, and cropland $(0.21 \%)$. In addition to the land transformation from natural forests, the process of land transformation can come from shrubs of $8.92 \%$ with descriptions being forest and rubber plantations $(1.00 \%)$, palm oil $(4.39 \%)$, and agroforestry (3.52\%). In 2015 , the land use composition in the Typology I areas was natural forest $(16.95 \%)$, forest and rubber plantations (13.16\%), palm oil (28.97\%), agroforestry (22.34\%), shrubs $(14.60 \%)$, and other land uses such as transmigration, settlements, and cropland (3.98\%).

In the early 1990s, the land uses of Typology 2 areas composed of natural forest, forest plantation, palm oil, agroforestry, shrubs, and other uses for example settlements, with percentage values of $51.97 \%, 0.70 \%, 4.99 \%, 30.48 \%$, $4.92 \%$ and $4.92 \%$ respectively. During the period of $1990-$ 2015 , around $17 \%$ of the natural forest were converted to forest plantation and rubber estates $(2.77 \%)$, palm oil $(4.28 \%)$, agroforestry $(5.18 \%)$, shrubs $(4.76 \%)$, and other landuse such as transmigration, settlements and cropland $(0.01 \%)$. In addition to land transformation from natural forests, the process of land transformation can come from shrubs of $1.78 \%$ with descriptions being forest and rubber plantations $(0.18 \%)$, palm oil $(0.62 \%)$, and agroforestry $(0.98 \%)$. In 2015 , the land use composition in the Typology I areas was natural forest $(34.97 \%)$, forest and rubber plantations $(3.65 \%)$, palm oil $(9.47 \%)$, agroforestry (36.64\%), and shrubs (7.90\%).

The forest transition theory by Mather (1992) raises the phenomenon of widespread forest resilience over time. The resilience of forest ecosystems is an essential prerequisite to sustainable development of forest ecosystems and socioeconomic system as a way of adapting to climate change (Yan et al. 2011). Forest transition pathways related with modernization process and economic development (Mather 2007). Many situations in some places becoming increased forest area phase such as economic development has created enough non-farm jobs, labor scarcities, scarcity of forest products, government intervention on promoting conservation and reforestation programs (Rudel et al. 2005), and also radical change policy as like privatisation forest land in European, devolution of forest land in Viet Nam, Join Forest Management in India, Natural Forest Conservation Program in China (Mather 2007). Countries which possess a large area of forests such as Indonesia and Brazil have developed forest transitions in relatively long decline phases due to expanding markets. (Rudel et al. 2005), even though government intervention in various eras has carried out forest rehabilitation (de Jong 2010). We have tracked the development of tropical forest transitions in Indonesia at the landscape scale.

Characterization of the forest transition development at the landscape level requires formation on typology model. At the landscape, there is spatial heterogeneity that has interaction, exchange, and influence on biotic and abiotic (Turner 1989). The spatial heterogeneity creates the potential for forest transitions to be very diverse. Our research found that the potential spatial characteristics of forest transitions have proximity to the spatial characteristics of demographic transitions, especially the population growth rate. The forest transition typology development in the Northern Konawe and Konawe districts were based on the population density and the extent of dry land and cropland (Setiawan et al. 2015).

Furthermore, the forest transition typology built in Jambi Province was based on the population density and the extent of cultivation land (Wijaya et al. 2015). Sulistiyono et al. (2015) developed forest transition typology in the Sumatra Island base on the growth rate of farm households. Thus, spatial location differences show fundamental differences in typology development. We found a simple spatial typology model in predicting the classification of forest transition development regions, even though in each region was affected by various complex forest transition pathways.

The characteristic profile of the typologies transition can be seen in Table 6. Characteristics in Typology 1 have a rapid demographic transition, biophysical change, and economic growth. Demographic transition characteristics in Typology 1 region, i.e. high forest area per capita and rapid population growth rates, caused a rapid process of forests transition. This has an impact on rapidly biophysical changes, such as changes in natural forest, the development of forest 
Table 6 Typical characteristics profile of forest transition

\begin{tabular}{|c|c|c|}
\hline Characteristics & Typology 1 & Typology 2 \\
\hline \multicolumn{3}{|l|}{ Demographic transition } \\
\hline Population growth rate (thousand people year ${ }^{-1}$ ) & Rapid (14.5) & Slow (3.5) \\
\hline Forest per capita (hectare people ${ }^{-1}$ ) & High (0.39) & Low $(0.14)$ \\
\hline \multicolumn{3}{|l|}{ Biophysical changes } \\
\hline Natural forest changes in $\left(\right.$ ha year $\left.{ }^{-1}\right)$ & Rapid (1.88) & Slow $(0.68)$ \\
\hline Forest and rubber plantation growth $\left(\%\right.$ year $\left.{ }^{-1}\right)$ & Rapid (0.52) & Slow $(0.11)$ \\
\hline Agroforestry development $\left(\%\right.$ year $\left.^{-1}\right)$ & Rapid (0.43) & Slow $(0.20)$ \\
\hline Palm development $\left(\%\right.$ year $\left.^{-1}\right)$ & Rapid(1.08) & Slow \\
\hline Scrub development $\left(\%\right.$ year $\left.{ }^{-1}\right)$ & Decrease $(-0.17)$ & Increase $(0.13)$ \\
\hline Elevation (m msl) & Low (29) & High (452) \\
\hline \multicolumn{3}{|l|}{ Economic growth } \\
\hline GDRP per capita growth rate (million people ${ }^{-1}$ year $^{-1}$ ) & Rapid (4.2) & Slow (2.5) \\
\hline GDRP per capita (million people ${ }^{-1}$ ) & High (89.7) & Low (26) \\
\hline
\end{tabular}

plantations, rubbers, and palm-oils. These are due to the land converted value more than the land value if it remains a primary forest (Barbier et al. 2010). This creates a residue of ineffectiveness in the early phase of the transition with the formation of a very high bush, but over time it tends to decrease. As the overall process of forest transition takes place, economic growth is running relatively rapidly compared to Typology 2. The indicator is GRDP per capita growth rate is working quickly, and the GRDP per capita is getting high. Vulnerability to high opportunities for ecological disasters as well as areas that belong to a high potential class of land fires and smoke disasters (Albar et al. 2016). The final goal of land burning during the land clearing process is to increase the value of the land (Purnomo et al. 2017).

Areas under of Tipology 2 were characterized by very low demographic transition, biophysical change, and economic development (Tabel 6). Demographic transition characteristics in Typology 2 region, i.e. small forest area per capita and slow population growth rates, caused a slow process of forest transition. With these characteristics, the biophysical changes that occur are slow enough to transform natural forests into other land uses for cultivation purposes. Biophysical changes that getting slow resulted in low residual processes at the beginning phase of transition with very low shrub growth. The impact of this process is economic development is relatively slow. The indicator is GRDP the per capita growth rate and GRDP per capita are working slowly.

From the phenomenon of various typologies above, there is a relation between demography transition, forest transition, and economic growth. Increased regional development in certain phases has been observed in areas with high population growth (Easterlin 1967). Areas classified as rapid demographic transitions showing high land use changes, especially for cultivation purposes, compared to slow demographic transition areas. Areas of high population growth have a high chance of spurring innovation and abandoning traditional behavior (Easterlin 1967). From the 140 countries tested, population pressure is a major factor in a country's land transformation (Kothke et al. 2013). Increasing population growth affects the deforestation phase, and the subsequent phase of reforestation affected by slowing population growth (Mather 1992; Mather and Needle 2000; Barbier et al. 2010; Yackulic et al. 2011), which is in line with the study results. Demographic transition tends to have a high phase then towards slow population growth- phase (Kirk 1996). Typology 1 region with high growth rate characteristic is dominated by region in Riau Province which indicates a slowing of population growth rate in the last period. From BPS data, the annual population growth rate of Riau Province in the period of 1980-1990, 1990-2000,2000-2010 and 2010-2016 were 4,3\%, 4,35\%, $3,58 \%$, and $2,59 \%$, respectively. The increasing economic growth rate affects the decline in mortality, and then mortality affects the decline in fertility (Ranganathan et al. 2015). The orientation of regional development along with the forest transition process has varied spatially differences in every spatial variation in the landscape level. In maintaining and or increasing the forest, transition stage is a policy choice.

Areas classified as Typologies 1 and 2 were influenced by differences in land allocations and functions of permanent forests that imposed by the government. Thus, not all watershed areas are in line with the framework that the development of the forest transition controlled by the use of competition mechanism as a result of market and investment influences (Barbier et al. 2010). Typology 1 was dominated by the utilization area so that there tends to be a rapid forest transition, while Typology 2 was dominated as a protected area tends to occur in a slow forest transition. Indonesia has large of forest area by 120.7 million hectares, and $\pm 64 \%$ of forest area was controlled by the government (KLHK 2015), this intervention effects forest transition pathways. The forest transition development in the Typology 1 region was due to an increase in land value (Barbier et al. 2010) in the process of modernization and economic development (Mather 2007; Rudel et al. 2010). The forest transition development in the Typology 1 area was the result of increasing land value (Barbier et al. 2010) in the process of modernization and economic development (Mather 2007; Rudel et al. 2010). With the government intervention, in the watershed area, there was a Typology 1 region which experienced a modernization process, while a Typology 2 area was maintained by traditional culture. 


\section{Conclusions}

The characteristics of spatial diversity of forest transition have very close proximity to the spatial diversity characteristics of demographic transition. Using the population growth rate as an indicator of forest transition, typology model has an accuracy of $92 \%$. The typology model of forest transition forms two common typologies i.e. rapid forest transition and slow forest transition. Areas with rapid forest transition have a characteristic profile of rapid demographic transitions, biophysical changes, and economic growth, while areas with slow forest transition will experience otherwise. This study provides input in grouping the potential transition areas by using spatial diversity of demographic transitions with population growth rate indicators as an indicator. Furthermore, managing and mitigating of forest transition impacts should be conducted by separating the various typologies of areas and considering characteristic profiles in each typology.

\section{Acknowledgment}

This article is part of the dissertation of the first author. The author presents the deepest appreciation to the Ministry of Environment and Forestry, the Republic of Indonesia for Doctoral scholarship. We would like to express our greatest appreciation and gratitude to the reviewers of this research article for correction.

\section{References}

Albar I, Jaya INS, Saharjo BH, Kuncahyo B. 2016. Spatiotemporal typology of land and forest fire in Sumatera. Indonesian Journal of Electrical Engineering and Computer Science 4:83-90. https://doi.org/10.11591/ ijeecs.v4.i1.

Antle JM, Heidebrink G. 1995. Environment and development: Theory and international evidence. Economic Development and Cultural Change 43:603-625.

Bae JS, Joo RW, Kim Y-S. 2012. Forest transition in South Korea: Reality, path, and drivers. Land Use Policy 29:198-207. https://doi.org/10.1016/j.landusepol. 2011.06.007

Barbier EB, Burgess JC. 2001. The economics of tropical deforestation. Journal of Economic Surveys 15:413-433. https://doi.org/10.1111/1467-6419.00144

Culas RJ. 2012. REDD and forest transition: Tunneling through the environmental Kuznets curve. Ecological Economics 79:44-51. https://doi.org/10.1016/j.ecole con.2012.04.015

Easterlin RA. 1967. Effects of population growth on the economic development of developing countries. The ANNALS of the American Academy of Political and Social Science 369:98-108. https://doi.org/10.1177/ 000271626736900110.

Ehrhardt-Martinez K, Crenshaw EM, Jenkins JC. 2002. Deforestation and the environmental Kuznets curve: A cross-national investigation of intervening mechanisms.
Social Science Quarterly 83:226-243. https://doi.org/10. 1111/1540-6237.00080.

Ewers RM. 2006. Interaction effects between economic development and forest cover determine deforestation rates. Global Environmental Change 16:161169. https://doi.org/10.1016/j.gloenvcha.2005.12.001.

FAO. 2015. Global forest resource assesment 2015. Rome: Food and Agriculture Organization of The United Nations

Geist HJ, Lambin EF. 2002. Proximate causes and underlying driving forces of tropical deforestation. BioScience 52:143150. https://doi.org/10.1641/00063568(2002)052[0143:pcaudf]2.0.co;2.

Grainger A. 1995. The forest transition: An alternative approach. Area 27: 242251.

Hardin G. 1968. The tragedy of the commons. Science 162:1243-1248. https://doi.org/10.1126/science.162. 3859.1243

Hosonuma N, Herold M, De Sy V, De Fries RS, Brockhaus M, Verchot L, Angelsen A, Romijn E. 2012. An assessment of deforestation and forest degradation drivers in developing countries. Environmental Research Letters 7:1-12. https://doi.org/10.1088/17489326/7/4/044009.

Jaya INS. 2015. Analisis Citra Digital: Prespektif Penginderaan Jauh untuk Pengelolaan Sumberdaya Alam. Bogor: IPB Press.

Kanninen M, Murdiyarso D, Seymour F, Angelsen A, Wunder S, German L. 2009. Apakah hutan dapat tumbuh di atas uang?: implikasi penelitian deforestasi bagi kebijakan yang mendukung REDD. Bogor: CIFOR

Kirk D. 1996. Demographic transition theory. Population Studies 50:361-387. https://doi.org/10.1080/003247 2031000149536.

Köthke M, Leischner B, Elsasser P. 2013. Uniform global deforestation patternsAn empirical analysis. Forest Policy and Economics 28:23-37. https://doi.org/10. 1016/j.forpol.2013.01.001.

Kuznets S. 1955. Economic growth and income inequality. The American Economic Review 45:1-28.

Lambin EF, Meyfroidt P. 2011. Global land use change, economic globalization, and the looming land scarcity. Proceedings of the National Academy of Sciences of the United States of America 108:3465-3472. https://doi.org/10.1073/pnas.1100480108.

Mather AS. 1992. The forest transition. Area 24:367-379.

Mather AS. 2007. Recent Asian forest transitions in relation to forest transition theory. International Forestry Review 9:491-502. https://doi.org/10.1505/ifor.9.1.491. 
Mather AS, Fairbairn J. 2000. From floods to reforestation: The forest transition in Switzerland. Environment and History 6:399-421.

Mather AS, Fairbairn J, Needle CL. 1999a. The course and drivers of the forest transition: The case of France. Journal of Rural Studies 15:65-90. https://doi.org/10. 1016/s0743-0167(98)00023-0.

Mather AS, Needle CL. 1998. The forest transition: A Theoretical basis. Area 30:117-124.

Mather AS, Needle CL. 2000. The relationships of population and forest trends. The Geographical Journal 166:2-13.

Mather AS, Needle CL, Fairbairn J. 1999b. Environmental Kuznets curves and forest trends. Geography 84:55-65.

MoEF. 2017. Rekalkulasi Penutupan Lahan 2015. Jakarta: Ministry of Environment and Forestry.

Purnomo H, Shantiko B, Sitorus S, Gunawan H, Achdiawan R, Kartodihardjo H, Dewayani AA. 2017. Fire economy and actor network of forest and land fires in Indonesia. Forest Policy and Economics 78:21-31. https://doi.org/ 10.1016/j.forpol.2017.01.001 .

Ranganathan S, Swain RB, Sumpter DJT. 2015. The demographic transition and economic growth: implications for development policy. Palgrave Communications 1:1-8. https://doi.org/10.1057/pal comms.2015.33

Rijal S, Saleh MB, Jaya INS, Tiryana T. 2016. Deforestation profile of regency level in Sumatera. International Journal of Sciences: Basic and Applied Research $25: 385-402$.

Rudel TK, Coomes OT, Moran E, Achard F, Angelsen A, Xu J, Lambin E. 2005. Forest transitions: towards a global understanding of land use change. Global Environmental Change 15:23-31. https://doi.org/10.1016/j.gloenvcha. 2004.11.001.
Rudel TK, Schneider L, Uriarte M. 2010. Forest transitions: An introduction. Land Use Policy 27:95-97. https://doi.org/10.1016/j.landusepol.2009.09.021.

Samsuri, Jaya INS, Kusmana C, Murtilaksono K. 2014. Restoration index of degraded tropical forest landscape in Batang Toru Watershed, North Sumatera Indonesia. Biotropia 21:111-124. https://doi.org/10.11598/btb. 2014.21.2.5.

Setiawan H, Jaya INS, Puspaningsih N. 2015. Model spasial deforestasi di Kabupaten Konawe Utara dan Konawe Provinsi Sulawesi Tenggara. Media Konservasi 20:166-176.

Suhendang E. 2013. Pengantar Ilmu Kehutanan. Bogor: IPB Press.

Sulistiyono N, Jaya INS, Prasetyo LB. 2015. Spatial model of deforestation in Sumatera Islands using typological approach. Jurnal Manajemen Hutan Tropika 21:99-109. https://doi.org/10.7226/jtfm.21.3.99.

Turner MG. 1989. Landscape ecology: The effect of pattern on process. Annual Review of Ecology and Systematics 20:171-197. https://doi.org/10.1146/annurev.es.20. 110189.001131 .

Wijaya PA, Saleh MB, Tiryana T. 2015. Spatial model of deforestation in Jambi Province for the period 1990-2011. Jurnal Manajemen Hutan Tropika 21:28-137. https://doi.org/10.7226/jtfm.21.3.128.

Xu J, Yang Y, Fox J, Yang X. 2007. Forest transition, its causes and environmental consequences: empirical evidence from Yunnan of Southwest China. Tropical Ecology 48:137-150.

Yan H, Zhan J, Zhang T. 2011. Resilience of forest ecosystems and its influencing factors. Procedia Environmental Sciences 10:2201-2206. https://doi.org/ 10.1016/j.proenv.2011.09.345. 